\title{
SOME EFFECTS OF ARTIFICIAL ILLUMINATION ON REPRODUCTION IN THE WIITE-FOOTED MOUSE, PEROMYSCUS LEUCOPUS NOVEBORACENSIS
}

\author{
WAYNE L. WHITAKER \\ Department of Anatomy, University of Miehigan, Ann Arbor ${ }^{1}$
}

FOUR FIGURES

Attempts to discover experimentally the relation between the length of day and the seasonal changes in reproductive activity of animals were first made by Rowan in 1924 and 1925. He was primarily interested in finding the natural stimulus to bird migration, and had observed, as had others, that the gonads of birds are changing in size during the migratory seasons. His juncos, trapped locally in Edmonton, Alberta, Canada, in the summer and fall of 1924 were given artificial light of increasing daily duration during the fall and winter in unheated outdoor aviaries. Definite increases in testicular sizes were found in late November and December when the testes are normally at the winter minimum (Rowan, '25).

From this first study the problem is being carried forward by many investigators. To attempt a general survey of their work seems entirely unwarranted since adequate reviews are already available, such as: Marshall ('36), Bissonnette ('36, '37), and Rowan ('38 a, '38 b). However a tabulation of the animals chiefly used in these investigations with brief notes as to the results is given below (table 1). Since the present research deals with a mammalian form, some discussion of previous work on mammals is included.

\footnotetext{
${ }^{1}$ Contribution from the Department of Zoology, University of Michigan.
} 
'IABI」H' 1

Animals on which experiments have been attenpted to determine the effect of light on the reproductive functions

\begin{tabular}{|c|c|c|c|}
\hline BMRDS & LIGHT TIREATM MFNT & RESULTS & INVESTIGATORS \\
\hline Bobolink, tanager & Inc. after decrease & Winter singing & Beebe ('08)* \\
\hline Junco & Increase in fall & Gonadal increase & Rowan ('25) \\
\hline Crow & Increase in fall & Migration disturbed & Rowan ('30) \\
\hline Starling & Inerease in fall & Testieular growth & Bissonnette ('30) \\
\hline Dove & Tnerease in fall & Egg laying advanced & Cole ('33) \\
\hline Domestic hen & Winter lighting & Egg laying advaneed & Many workers \\
\hline $\begin{array}{l}\text { Zosterops palpebrosa } \\
\text { japonica }\end{array}$ & $\begin{array}{l}\text { Periodie light ine. } \\
\text { thrice annually }\end{array}$ & $\begin{array}{c}\text { Three seasons of } \\
\text { mating songs }\end{array}$ & Miyazaki ('34) \\
\hline Domestic duck & Ine. during fall & Sexual activation & Benoit ('34) \\
\hline English sparrow & Ine. during fall & Sexual activation & Ivanova ('35) \\
\hline English sparrow & Ine. during fall & Test. dev. in juv. & Riley ('36) \\
\hline English sparrow & Ine. during fall & Testieular dev. & $\begin{array}{l}\text { Kiosehbaum and Ringoen } \\
\text { ('36) }\end{array}$ \\
\hline Einglish sparrow & Dec. during spring & Retards development & $\begin{array}{l}\text { Kirschbaum and hingoen } \\
\text { ('36) }\end{array}$ \\
\hline Quail & Ine. in fall & Egg laying advanced & Bissonnette, Csech ('36 a) \\
\hline Quail and pheasants & Tne. in fall & Gonad wt. increased & $\begin{array}{l}\text { Clark, Leonard, Bump } \\
\text { ('36) }\end{array}$ \\
\hline Phersants & 1ne. in fall & Winter eggs at $0^{\circ} \mathrm{F}$. & Martin ('35) \\
\hline Pheasants & Ine. in fall & Winter eggs & Bissommette, Csech ('36 b) \\
\hline Grouse & Ine. in fall & Gonad wt. increased & $\begin{array}{l}\text { Clark, Leonard, Bump } \\
\text { ('36) }\end{array}$ \\
\hline Grouse, pheasant & Dark in spring & Inhibits sex dev. & $\begin{array}{l}\text { Clark, Leonard, Bump } \\
\text { ( } 36)\end{array}$ \\
\hline Turkey & Ine. in fall & Winter eggs & Scott and Payne ('37) \\
\hline Guinea fowl & Ine. in fall & No response & Scott and Payne $(37)$ \\
\hline \multicolumn{4}{|l|}{ MAMMALS } \\
\hline Microtus & $\begin{array}{l}\text { Long days vs. } \\
\text { short days }\end{array}$ & $\begin{array}{l}\text { Greater litter pro- } \\
\text { Auction in Iong day }\end{array}$ & Baker and Ranson ('32 a) \\
\hline Ferret & Ine. in fall & Estrus in winter & Bissonnette (32) \\
\hline Fcrret & Ine. in fall & Estrus in winter & $\begin{array}{l}\text { Allanson, Rowlands and } \\
\text { Parkes ('34) }\end{array}$ \\
\hline Ferret & $\begin{array}{l}\text { Various ware- } \\
\text { lengths }\end{array}$ & $\begin{array}{l}\text { Only visible light } \\
\text { effective }\end{array}$ & $\begin{array}{l}\text { Marshall and Bowden } \\
\quad \text { ('34) }\end{array}$ \\
\hline Hedgehog & Ine. in winter & Not effective & Allanson, Deanesly ('34) \\
\hline Guinea pig & $\begin{array}{l}\text { Darkness or light } \\
\text { eontinuously }\end{array}$ & Not effective & I)empsey et al. ('34) \\
\hline Rabbit (domestie) & Absence of light & No effect & Smelser et al. ('34) \\
\hline Citcllus & Inc. in winter & No effect & Johnson and Gann ('33) \\
\hline Peromyscus & Ine. in fall & $\begin{array}{l}\text { Breeding advanced } \\
\quad 2 \text { months }\end{array}$ & Whitaker ('36) \\
\hline $\begin{array}{l}\text { RaccoOn } \\
\text { O'HER VERTEBRATES }\end{array}$ & Ine. in fall & $\begin{array}{l}\text { Breeding advanced } \\
\quad 6 \text { wecks }\end{array}$ & Bissonnette, Csech ('37) \\
\hline Stickleback & Increase & No effect & Craig-Bennet ('31) \\
\hline Brook trout & Dee. in summer & Early spawning & Hoover, Hubbard ('37) \\
\hline Lizard (Anolis) & Inc. in winter & $\begin{array}{l}\text { Advanced spermato- } \\
\text { genesis }\end{array}$ & Clausen, Poris ('36) \\
\hline Horned lizard & Inc, in winter & No effect & Mellish ('36) \\
\hline Turtle & Inc. in winter & $\begin{array}{l}\text { Modification of eycles } \\
\text { of spermatogenesis }\end{array}$ & Burger ('37) \\
\hline
\end{tabular}

* This work was a study of factors inducing plumage change in birds. The disturbance of plumage sequence and unseasonal mating songs is now believed to be due to sexual condition.

Note: This tabulation is by no means complete. It merely lists an early report of each worker on various animals which have been the subject of planned experimentation. 
Manipulation of day length and light intensity, under the conditions of the experiments, has failed to show any definite effect on reproduction in the rabbit (Smelser, Walton and Wetham, '34), the guinea pig (Dempsey, Meyers, Young and Jennison, '34), the hedgehog' (Allanson and Deanesly, '34), or the ground squirrel (Wolls, '35 a).

The ferret, a monestrous animal with a definite breeding season even under laboratory conditions, has received attention from several workers. Bissonnette ('32) produced full estrus in three females within 34 to 64 days by adding 6 hours of artificial light daily starting October 12. Hill and Parkes ('33) confirmed this, but their hypophysectomized animals were unresponsive. Males, also, were brought into sexual condition when Bissonnette and Bailey ('36) were able to get fertile matings as early as November 29 by light treatment alone.

In a converse manner Hill and Parkes ('34) found that almost continuous darkness from January 24 did not retard the approach of the breeding condition, but Bissonnette ('35 b) reported that a short day of $8 \frac{1}{2}$ hours from November 10 did retard the normal spring gonadal development. Furthermore, anestrum was induced in the female by reduction of the day length even during the normal breeding season.

Raccoons (Bissonnette and Csech, '37), under the influence of Mazda light, artificially lengthening the day from October $10 \mathrm{on}$, failed to experience any pseudo-hibernation, mated as early as December 10, and delivered litters as early as February 27 , which is at least 4 or 5 weeks earlier than the normal controls. Parturition, lactation, and care of the young were normal even at sub-zero conditions. The same authors ('38) reported that second litters were delivered in late summer by females stimulated to produce an early first litter.

Historically, the first mammal studied in this regard was Mierotus agrestis. This was done by Baker and Ranson (' 32 a, $32 \mathrm{~b}, 33$ ), who were interested in determining the effect of light, temperature, and seasonal diet on the breeding season. of these only light was effective. Litter production was mark- 
edly greater in the artificial 15-hour days than under 9-hour day conditions.

\section{MATERIAL AND METHODS}

The white-footed mouse, Peromyscus lencopus noveboracensis, was chosen as the subject for this study because it was readily procurable locally, it breeds well in captivity, and is small enough that a fair-sized colony could be maintained with the facilities available. It differs from the ferret and raccoon by being unquestionably polyestrous. It is unlike the former in that it is a wild form, not domesticated. It resembles both and differs from the laboratory rabbit and guinea pig by having a definite anestrous season in nature. It most resembles Microtus in all these characteristies but is generally considered to be much more definitely nocturnal in habits.

From more than 2 years' observation Burt (manuseript in press) has found March 23 to be the earliest date of delivery of a litter as a result of conception in the wild. Most of the production oceurs in April, May and June. There is a slump in July, which is unaccounted for at present, and then a revival of litter production in late August, September, and October. There are few litters produced in November, none in December, January, or February in the field near Ann Arbor, Michigan, where Burt's observations were made and where the original animals of the experimental colony were trapped.

The variability of individuals within the colony should be mentioned. This was most noticeable in the first and second generations of laboratory born animals. Weights of mature individuals varied from $14 \mathrm{gm}$. to more than $40 \mathrm{gm}$.; although those near either extreme were usually infertile. The age at which the adult pelage was acquired was quite as variable; vaginal canalization, also, occurred as early as 18 days of age in one female and as late as 3 months in another. Since it is very probable that other less easily observed variations exist in the individuals of the group, it is necessary to consider variability in viewing the results. 
Criteria of breeding condition. Though litter production and autopsy findings are important in determining the sexual condition, externally observable criteria also were used as far as possible in this investigation so that the same intact animal might be observed periodically over a considerable time. Such criteria are deseribed below.

The males are certainly sterile, in anestrum, if the testes are abdominal or too small to be palpated. The animal is probably fertile if the testes are scrotal in position and approximately full size. The intermediate stages are questionable. By practical experience it was found that the male was sterile unless the testes were at least half size or the epididymides could be easily palpated. At the periodic examinations, the testes were recorded as being full size, half size, quarter size scrotal, quarter size abdominal, merely palpable, or not detectable by external examination. In the later handling of the data only the first two conditions were considered as indicative of fertility.

Adult females are definitely in anestrum when the vagina is closed by a membrane. In the white-footed mouse it appears as illustrated in figure 1. Miller (1893) believed that this membrane, which is not to be confused with the appearance of a closure due to the approximation of the lips of the vaginal orifice, was ruptured only by the mechanics of copulation or parturition. Certainly in the animal under consideration copulation is not necessary for membrane rupture, because in immature females segregated from males the vagina opens at an age not apparently greater than in those mated. Of several score examinations of pregnant animals, one female (no. 232) was observed during three pregnancies as having a closed vagina. This membrane in the pregnant animal cannot be confused with that present in anestrum, because of the differences in other features of the vulva. A female with an open vagina may be, but is not necessarily, in a condition to breed, for it was found at autopsy that a few of those with open vaginas had non-follicular ovaries and uteri of infantile size. These must have been sterile but the data based on external observa- 
tions can be eorrected only after autopsy at the end of the experiment.

Obviously such external observations cannot be given as absolute criteria of fertility. Re-mating with individuals of known fertility might give the true answer but such was never done for fear of too much disturbance of the animals. For the same reason vaginal smears were not made. All animals were sacrificed at the end of the experiment, the reproductive

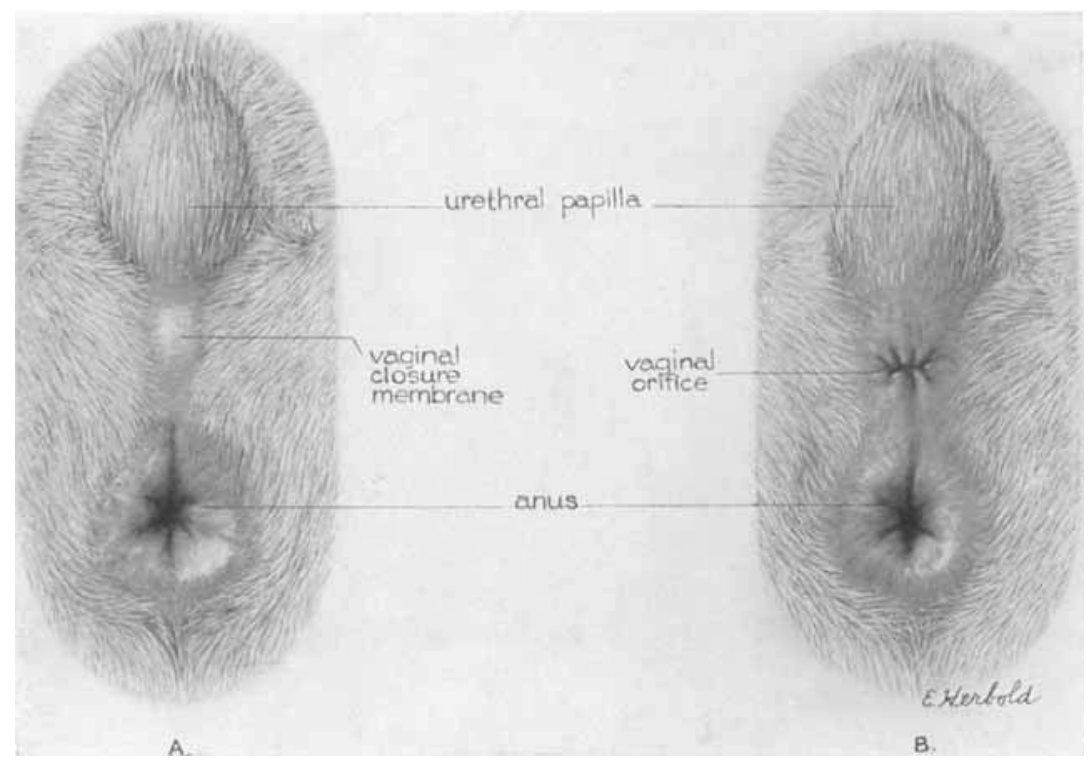

Figure 1

organs preserved, and doubtful cases examined microscopically for gonadal condition.

A preliminary experiment (Whitaker, '36) indicated that Peromyscus leucopus noveboracensis was responsive to day length, since added light from a General Electric Sunlamp from September to December indueed the breeding condition about 8 weeks earlier in the test animals than in the controls. This experiment was of the type usually performed by preceding workers-increasing daily light duration for a few months 
during the fall and winter. It was believed that this demonstrated response was only a part of the proof needed to show that light was an important factor in determining the natural breeding season of the species. It was felt that conditions should be set up such that diet, temperature, humidity, ventilation, and eage conditions should not only be the same for the entire colony but also should change throughout the year as little as possible. In such an environment the quite accurately controlled light should be the one variable. Further, individual animals should be subjected to decreasing as well as increasing days in the natural sequence. Continuous darkness and differing intensities of light should also be given attention. With these plans in mind the experiments which this paper reports were begun as described below.

\section{Subsequent Experiments Physical conditions of the experiments}

A sub-basement room 10 feet wide, 20 feet long and 7 feet high was selected because it was almost entirely free from any outside disturbances, had no natural light, and had a relatively small temperature variation. The room was divided into five compartments and ventilating ducts installed. Electric fans circulated the air within the room and drew in some from outside, thus keeping the air fresh and temperature and humidity equalized in the various compartments. From April 1936 when the experiment was started until the refrigeration equipment was installed in March 1937, the temperature varied only from $25^{\circ} \mathrm{C}$. in July to $19.5^{\circ} \mathrm{C}$. in December. From March 1937 to the end of the study a Frigidaire C550 blower coil, supplied by a 1-horsepower compressor thermostatically controlled, maintained the temperature at $11^{\circ}-12^{\circ} \mathrm{C}$. in all compartments except $\mathrm{V}$ where it varied between $4^{\circ}$ and $6^{\circ} \mathrm{C} .^{2}$ The humidity

\footnotetext{
${ }^{2}$ It was thought that the temperature selected was sufficiently low to discourage continuous breeding, for it was already becoming evident that, in this form, anestrum was more diffieult than the breeding condition to produce experimentally. It was not diseovered until later that this plan of inhibiting reproduction by a temperature of $11^{\circ} \mathrm{C}$. was ill-founded.
} 
was maintained very near to $50 \%$ continuously. These were the fixed conditions. The variable was light. ${ }^{3}$

The cages, to which were assigned one mated pair or four of one sex, were $8 \times 10 \times 15$ inches, made of wire mesh and rested on sawdust in enamel trays. Shredded paper was furnished in such quantity that the animals could build adequate nests and shelters. With the exception of one series they were never forced to remain exposed to the light, for they could easily hide in the nesting material. The diet, that of Dice ('34), consisting of a mixture of several cereals, meat scraps, cod liver oil, powdered milk and salt, was available in a food hopper at all times. Lettuce was given once each week, while water was supplied continuously.

The light was supplied by regular Mazda lamps. Compartments I and II were equipped with 200 watt lamps, furnishing from 15 to 32 foot eandle power of light at the cages, depending on the distance. Compartment III had a 10 watt lamp similarly placed, which furnished 2 f.c.p. at the nearest cages but less than 1 f.c.p. at most of them. Compartment IV had no light, while $V$ was fitted with a bulb of such a size as to produce an intensity similar to that on the animals in I. The brighter light was chosen arbitrarily, the dim bulb because it was believed the difference might be sufficient by contrast. A time switch turned the lights on and off according to a prearranged schedule, planned so that while $I$ and $V$ were in a midsummer light of 18 hours per day, II and III were receiving only 6 hours daily, as for example in September. (Refer to the day length curves in any of the figs. 2 to 4.) From that artificial solstice the length of the day in II and III increased $\frac{1}{2}$ hour each week to the artificial equinox in December, while the day length in $\mathrm{I}$ and $\mathrm{V}$ had been decreasing to 12 hours. In March compartments II and III reached the maximum of 18 hours of illumination daily and $\mathrm{I}$ and $\mathrm{V}$ were under mid-

${ }^{3}$ Sound intensities constituted another variable of unknown importance. Average values for each compartment, measured by Mr. Fdward Teal of the Physies Department, University of Michigan, were, in decibels and (American Standards Association Sound Lnits); I, 64.3 (5653); II, 63.6 (5436); III, 68.0 (7020); IV, 63.8 (5498); and $\mathrm{V}, 74.4(10920)$. 
winter light conditions. In short, the experimental solstices were arranged to fall at the time of the natural equinox so that neither group would have the advantage, if any, of having a "summer" season coinciding with that outdoors. Furthermore, the natural day and night were split so that the artificial noon and midnight came at 8:00 instead of 12:00.

In addition to the animals under these controlled conditions, a few were kept for observation outdoors (group VI), and a few others in a general heated animal room (group VII).

\section{Assignment of animals to series and groups}

All animals were admitted to the experimental conditions as young adults or as juveniles; each was numbered by ear and toe markings and its history recorded. The term series is used here to denote all those animals with a similar history that were admitted at the same time, usually eight to each compartment. A group is composed of all the animals under one experimental condition, for example, all animals assigned to compartment III were considered as comprising group III. When animals were being assigned to a series, any one litter was scattered as widely as possible and, with the exception of series $\mathrm{N}$, animals born in any compartment were distributed as equally as possible to all groups. All the animals were weighed periodically and examined for sexual condition (compare Criteria of Breeding Condition, p. 37).

\section{Results $^{4}$}

In order that the results of these experiments may be compared, attention is directed to the charts (figs. 2 to 4 ) which show the per cent of the various groups in reproductive condition as correlated with light in the environment throughout the 2-year period of observation.

Effect of variation in the daily duration of light. Comparison of groups I and II (fig. 2). The only difference between

\footnotetext{
4 For the complete data, the reader is referred to the Doctoral Dissertation of same title deposited in the University of Michigan General Iibrary.
} 
WAYNE L. WHITAKER

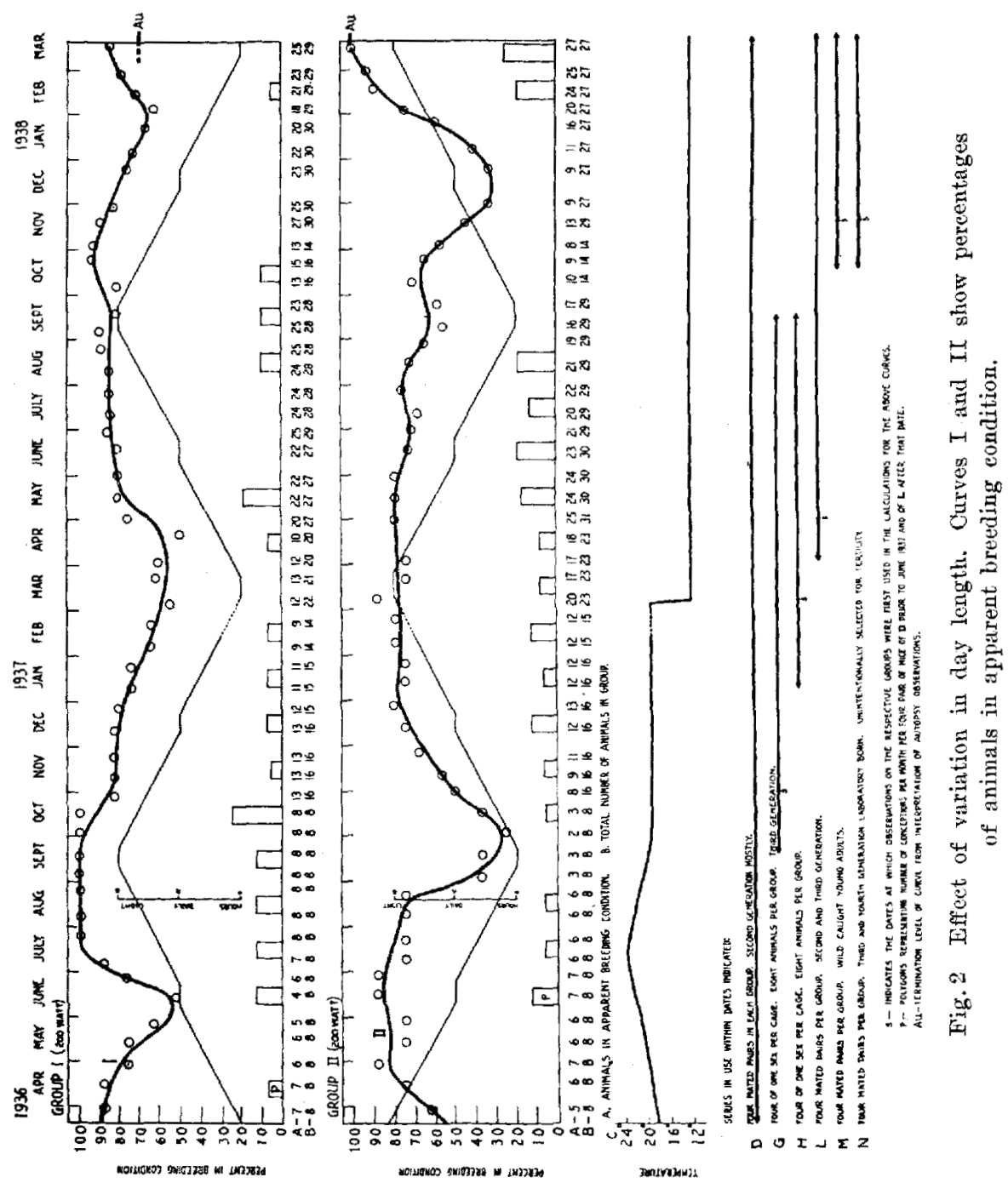


groups I and II is that of the length of the daily periods of artificial illumination, as indicated by the narrow diagonal lines of figure 2. The response of the animals to this changing environmental factor is shown by curves I and II which represent the percentage of the groups in apparent breeding condition, and by the polygons which indicate the monthly rate of conception.

At the beginning of the experiment, the mice of group I were removed from a room offering about 12 hours of daylight to the experimental compartment lighted only 6 hours per day. This was followed in about 6 weeks by a drop from $90 \%$ to $50 \%$ in the number in breeding condition. As the period of illumination increased, during July and August, the percentage rose to 100 and remained there until late October when the effect of shorter days became evident. In this group, a part of which were observed for 2 years, the lowest fertility occurred in March and April 1937 after the animals had been subjected to 6 months of decreasing day length. Sacrifice of one series of animals or the addition of new ones had little effect on the slope of the curves. The upturn of the curve in February and March 1938, while the day was still decreasing, is not explained. However, the amount of the upturn is not so great as at first apparent, for observations of the reproductive organs after sacrifice places the termination level of the curve about $15 \%$ lower, as shown by the broken line.

While group I was exposed to long days, group II was subjected to short periods of daily illumination. Accordingly, fertility was low at such times. In September and October 1936 only one of the eight animals failed to enter anestrum. A high level of breeding ability was observed during the three periods of long days. The retardation in the drop of curve II in the autumn of 1937 is not explained but the drop itself was doubtless due to the short day period just preceding. Autopsy observations support the data from external examination that all twenty-seven of the animals of group II were in breeding condition at the end of the experiment in March 1938. Litter production tended to follow the curve levels throughout. 
Comparison of curves I and II in their entirety shows that they are, in general, mirror images of each other, as the respective light curves are exactly. However, it is not necessary to limit the comparison to the appearance of the curve. As shown in table $2,98 \%$ of the mated animals exposed to long

TABLE 2

Statistical analysis of breeding condition relative to length of day-mated animals

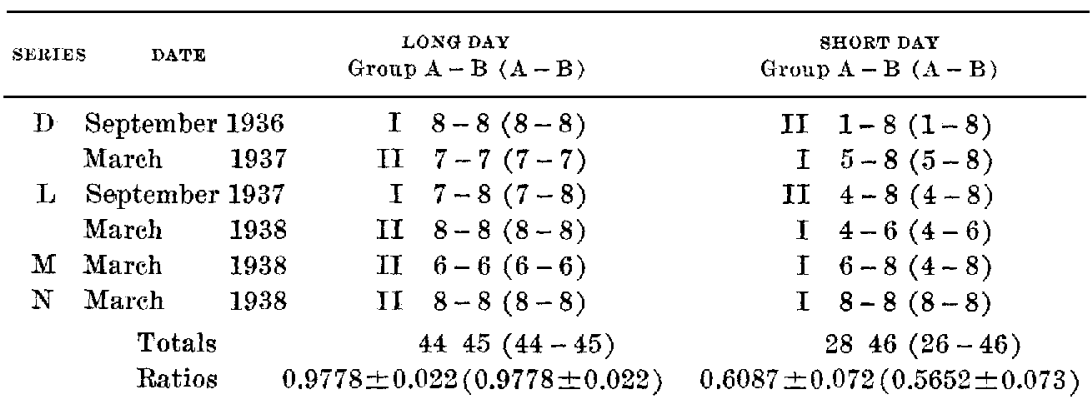

Difference of the ratios is 0.3691 , which is 4.93 times 0.0749 , the standard error of the difference. Inchuding autopsy corrections, the difference is $0.4126,5.43$ times the standard error, 0.076 .

Including also the unmated animals:

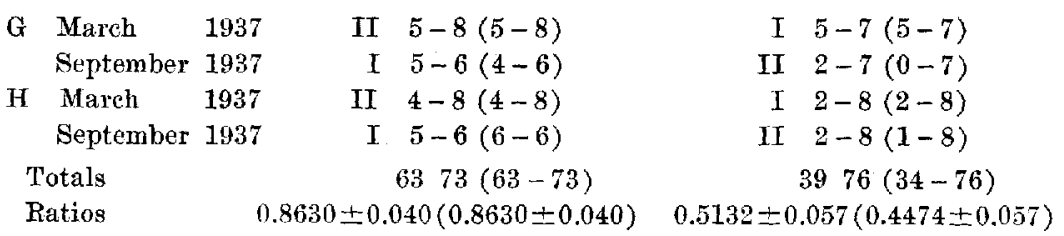

Difference of the ratios is 0.3498 which is 4.79 times 0.073 , the standard error of the difference. Including the autopsy corrections the difference is $0.4156,5.87$ times the standard error, 0.0707 .

$A$, animals maintaining an apparent breeding condition during the period indicated. B, total number of animals in the group at that time. Numbers in parentheses, same except where corrected by autopsy data.

days were in breeding condition, while $39 \%$ of those in short days became anestrous. Statistical analysis of these ratios shows that their difference is about five times the standard error of the difference. It is a practical certainty, therefore, that the difference is not due to chance, but that some environmental factor is operating. Inclusion of unmated animals 
tends to lower this figure slightly, while autopsy data increase it by lowering the ratio of fertile animals during short days. Few, if any, corrections can be made on the long day observations. The errors inherent in the procedure of judging sexual condition by external observation appear, thus, to have rendered the conclusions somewhat conservative.

Effect of continuous darkness. Comparison of groups I and IV (fig. 3). The environment of group IV differed from others only by the almost complete lack of light. Its curve of breeding condition percentages is compared with that of group I in figure 3. The general level of curve IV at 60 to $70 \%$ is striking. There is no support here for an "inherent rhythm" in animals deprived of all rhythmically varying factors of the environment. The difficulty of judging the sexual condition of animals, males especially, which were on the border line, as these were much of the time, is reflected in the considerable scattering of points on portions of the curve. Litter production in group IV was always low but one fertile pair was usually present.

Effect of variation of light intensity. Comparison of groups II and III (fig. 4). Group III, the "dim light" group, was illuminated by a 10-watt bulb furnishing light of about 1 foot candle power or less, at the cages. In contrast, group II used a 200-watt lamp at the same distance, but day lengths were the same at all times. There was about $30 \%$ more noise from the ventilating fans in III than in II, a fact that should be kept in mind until experimental consideration is given directly to the noise factor of the environment. The most notable difference between curves II and III (fig. 4) is that III fails to drop during short days as does II. Note especially the high level maintained during the short days of 1936. The one drop in November and December 1937 parallels that of II but is not so low. Neither has been explained unless it be due to the addition of young mice of series $M$ and $N$ to consideration at that time. In general, curve III is higher than II, and gives little indication of a tendency to seasonal breeding activity. The statistical significance of the difference between breeding 
WAYNE L. WHITAKER

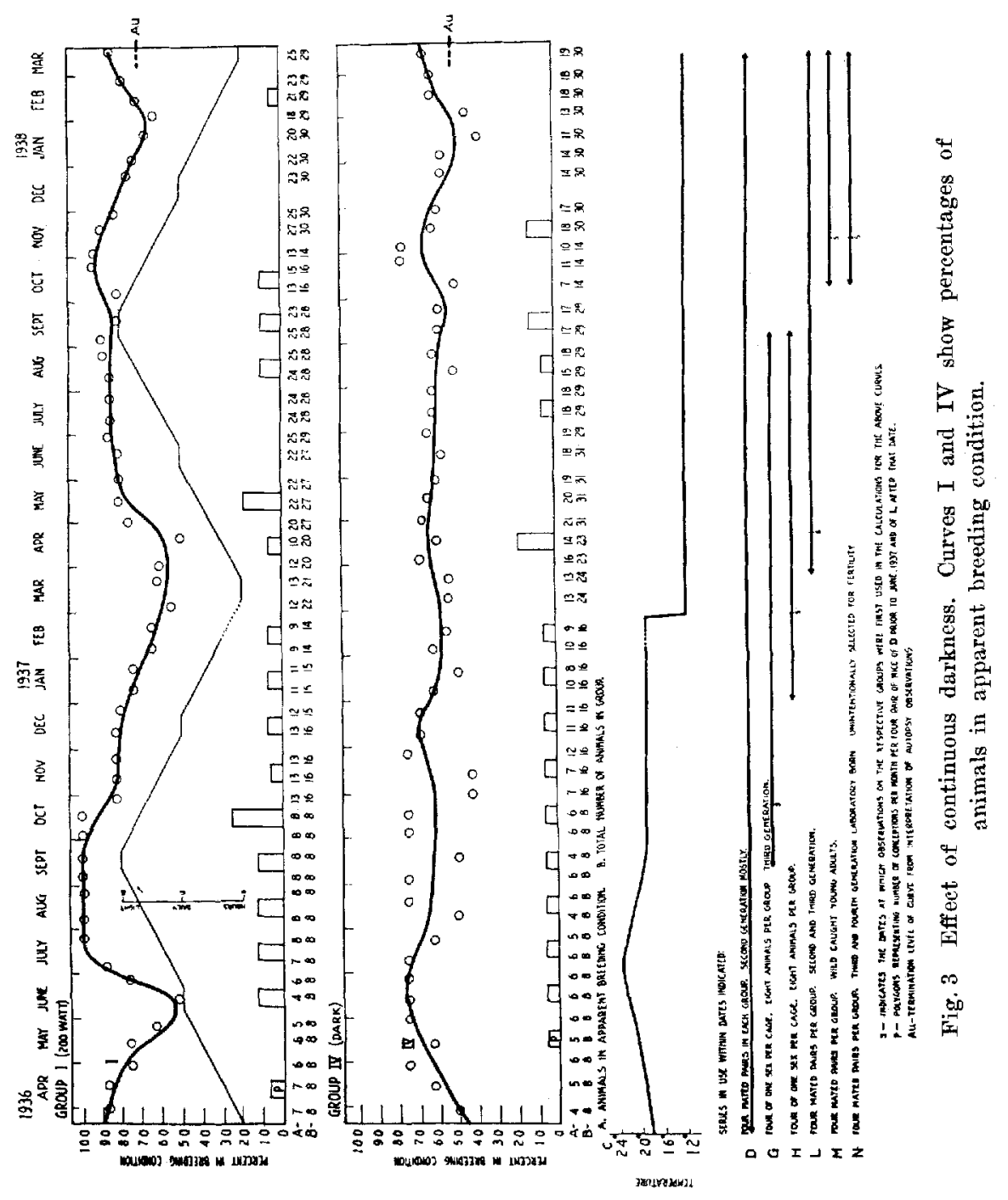




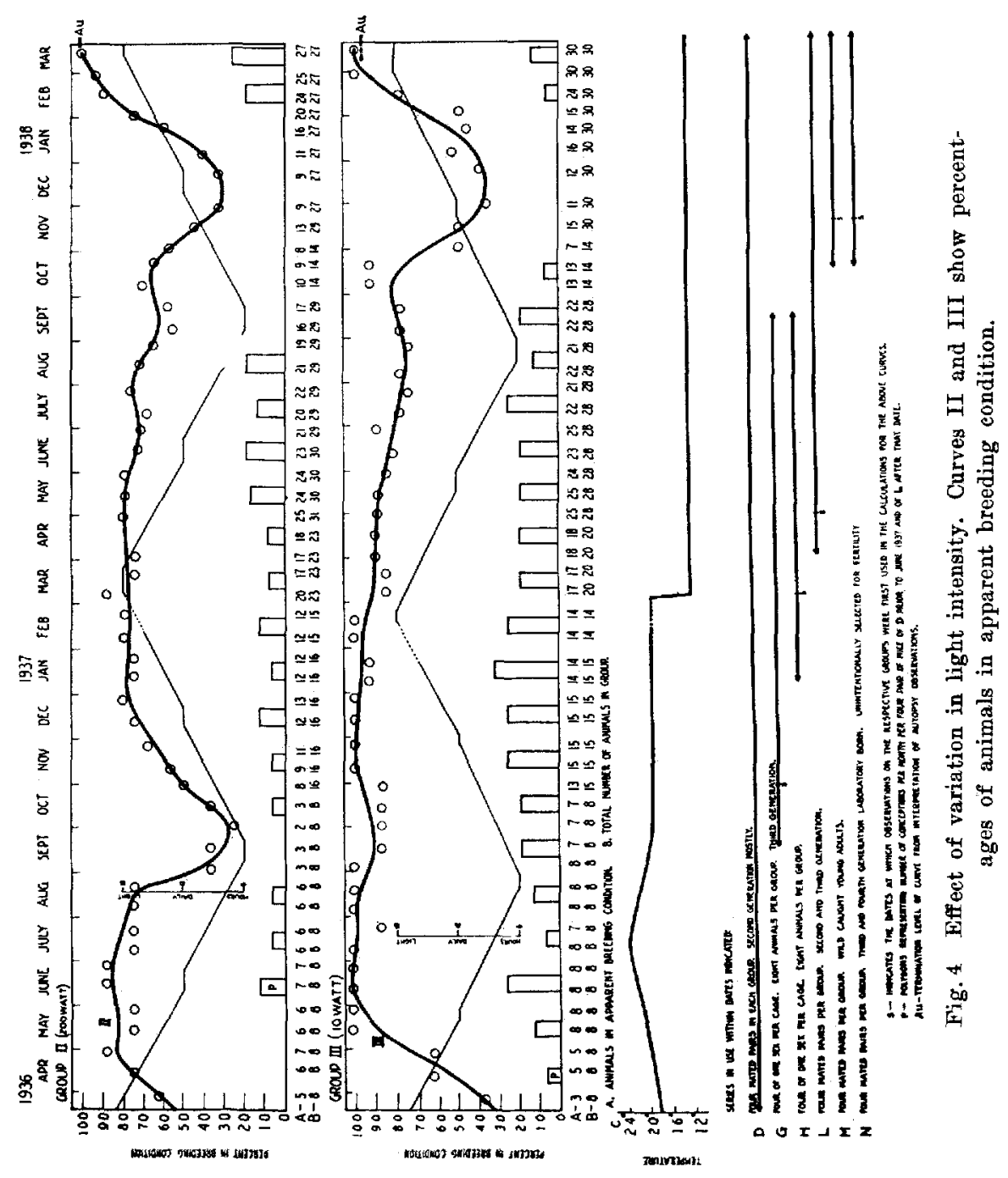


condition of the two groups at the periods of short days, the crucial point, may be determined (table 3 ). The ratio of breeding animals to the total number in group II was $0.19 \pm$ 0.070 . In III it was $0.62 \pm 0.090$. The difference is 0.43 and the standard error of the difference is 0.1144 . Since the difference is 3.77 times the standard error, it is apparent that some factor other than chance was operating to produce the difference.

Possible effects of temperature or noise. Comparison of groups I and V. Since only two series had representatives in group $\mathrm{V}$ it is realized that these results may not be so valid

TABLE 3

Analysis of breeding condition during short days relative to light intensity. Groups II and III

\begin{tabular}{|c|c|c|c|}
\hline \multirow{2}{*}{ SERIES } & \multirow{2}{*}{ DATE } & \multirow{2}{*}{$\begin{array}{c}\text { 200-WATT (II) } \\
A \mathrm{~B}\end{array}$} & \multirow{2}{*}{$\begin{array}{c}\text { I0-WATT (III) } \\
\text { A B }\end{array}$} \\
\hline & & & \\
\hline $\mathrm{D}$ & September 1936 & $1-8$ & $7-8$ \\
\hline G & September 1937 & $0-7$ & $3-5$ \\
\hline $\mathrm{H}$ & September 1937 & $1-8$ & $1-8$ \\
\hline I. & September 1937 & $4-8$ & $7-8$ \\
\hline \multicolumn{2}{|c|}{ Totals } & 631 & 1829 \\
\hline \multicolumn{2}{|c|}{ Ratios } & $0.19 \pm 0.070$ & $0.62 \pm 0.090$ \\
\hline
\end{tabular}

A, number of animals maintaining breeding condition during the short days. $B$, the total number in groups. Autopsy observation corrections are applied to $\mathrm{G}$ and $\mathrm{H}$.

as those of other phases of the experiment. However, it is quite apparent that the animals in the colder compartment $\left(4^{\circ}\right.$ to $6^{\circ} \mathrm{C}$.) were less inhibited by the short days of March 1938, when the investigation was terminated, than were those of compartment I with the same day length. Table 4 illustrates the point.

Thus, more than half, eight of fourteen, of the animals of I were anestrous at autopsy during short days, while only one of sixteen in the colder, noisier, and somewhat less intensely illuminated compartment $\mathrm{V}$ was judged to be in anestrum. Since these mice of group $\mathrm{V}$ did not come out into the light as did those of III in light considerably dimmer, it is believed 
that the difference in light intensity is not the factor producing the observed difference in response. Further, it is difficult to believe that a lower temperature would act as a stimulator of the sexual apparatus during the short day season, since it is the general opinion that low temperatures, near freezing point at least, tend to inhibit reproduction in rodents. If sound is responsible for the observed phenomena this is the first experimental evidence reported.

While this experiment was not planned to investigate the effects of sound as a determiner of reproductive activity and the results cannot be accepted as conclusive, they may be suggestive of future work.

\begin{tabular}{|c|c|c|c|c|c|c|c|}
\hline \multirow{5}{*}{$\begin{array}{l}\text { Group I } \\
\text { Series L } \\
\text { Series M }\end{array}$} & \multicolumn{3}{|c|}{ TABLE 4} & \multirow{2}{*}{\multicolumn{4}{|c|}{ RREEDIXG CONDITION }} \\
\hline & \multirow{3}{*}{$\begin{array}{l}\text { THMPP. } \\
{ }^{\circ} \mathrm{C} \text {. }\end{array}$} & \multirow{2}{*}{$\begin{array}{c}\text { IIGHT } \\
\text { f.c.p. }\end{array}$} & \multirow{2}{*}{$\begin{array}{l}\text { Sound } \\
\text { A.S.A.A. }\end{array}$} & & & & \\
\hline & & & & \multicolumn{2}{|c|}{ Apparent } & \multicolumn{2}{|c|}{ Autopsy } \\
\hline & & 34 & 4800 & \multicolumn{2}{|c|}{4 of 6} & \multicolumn{2}{|c|}{2 of 6} \\
\hline & $11-12$ & 17 & 6200 & 6 & 8 & 4 & 8 \\
\hline & & & & & Total & 6 & 14 \\
\hline \multicolumn{8}{|l|}{ Group V } \\
\hline Series L & $4-6$ & 17 & 12,950 & \multicolumn{2}{|c|}{8 of 8} & \multicolumn{2}{|c|}{7 of 8} \\
\hline \multirow[t]{2}{*}{ Series $M$} & $4-6$ & 15 & 11,000 & 8 & 8 & 8 & 8 \\
\hline & & & & & Total & $\overline{15}$ & 16 \\
\hline
\end{tabular}

'American Standards Association loudness units.

Autopsy observations on males. A comparison of the sexstimulating power of the various environments in use at the end of the experiments in March 1938 is made by examining autopsy records of males. Table 5 lists the average weights of one testis and one seminal vesicle from each of the males in groups I to VII. The groups are arranged in order of decreasing testicular weight. Those at the extremes, VI (outdoors) and VII (general animal room), include too few males to be significant, but it seems that other observations might well be made on that point. It was to be expected that animals in long days (group II) should stand high in the list, but they are exceeded somewhat by those in the cold and short days (group V). Group IV in continuous darkness had even smaller testes than those in the short days of group I. 
Comparing the response of series $\mathrm{M}$ (caught wild) and $\mathrm{N}$ (inbred stock) to the various environments of groups I, II, III, IV, and VI, testicular weights of seventeen males of M averaged $193 \mathrm{mg}$., and of eighteen animals of $\mathrm{N}, 207 \mathrm{mg}$. The average weights of seminal vesicles were 106 and $187 \mathrm{mg}$. respectively. It appears, then, that this unintentional selection for fertility in series $\mathrm{N}$ may be reflected in testicular size,

TABI: 5

Average weights in milligrams of testes and seminal vesicles with contents of animals of series $D, L, M, N$, March 1938 in order of decreasing testicular weights. The numbers in parentheses represent the number of animals used in the computation of the average weights

\begin{tabular}{lllrrrrr}
\hline & & D & L & M & N & $\begin{array}{r}\text { AENERAL } \\
\text { AVERAGE }\end{array}$ \\
\hline VI & Outdoors & Testes & & & $(2) 253$ & $(2) 208$ & $(4) 230.5$ \\
& & Sem ves & & & 159 & 227 & 193.2 \\
V & Short days, & Testes & & $(4) 265$ & $(4) 196$ & & $(8) 229.4$ \\
& cold & Sem ves & & 176 & 122 & & 149.1 \\
II & Long days & Testes & $(3) 211$ & $(4) 218$ & $(3) 212$ & $(4) 228$ & $(14) 218.0$ \\
& & Sem ves & 159 & 152 & 110 & 215 & 164.2 \\
III & Long days, & Testes & $(4) 178$ & $(3) 183$ & $(4) 221$ & $(4) 228$ & $(15) 203.6$ \\
& dim light & Sem ves & 106 & 169 & 151 & 212 & 158.8 \\
I & Short days & Testes & $(4) 145$ & $(3) 158$ & $(4) 149$ & $(4) 198$ & $(15) 163.0$ \\
& & Sem ves & 101 & 87 & 104 & 185 & 115.2 \\
IV & Dark & Testes & $(3) 155$ & $*$ & $(4) 114$ & $(4) 175$ & $(11) 147.3$ \\
& & Sem ves & 82 & & 33 & 119 & 77.2 \\
VII & Gen. animal & Testes & & & & $(3) 122$ & \\
& room & Sem ves & & & & 109 & \\
\hline
\end{tabular}

* Group IV of series L is omitted from this computation because these animals were given Antuitrin-S treatment prior to date of sacrifice.

and especially in testicular activity as indicated by seminal vesicle weights.

\section{Related Experiments}

Activity and light. Since it is believed by some that the length of daily periods of activity may have some part in the determination of the season of reproduction in some animals, a partial study of daily activity and choice of light or dark- 
ness was made. The apparatus, designed and built for this study, was described elsewhere (Whitaker, '37).

Results of studies made in compartments I and II with light of about 17 foot candle power confirm the general impression that this animal is primarily nocturnal. It was most active when the room was dark. Very little activity was registered while the lights were on, and most of the time was spent in the dark compartment of the cage, though visits to the light compartment were characteristically made for a minute or more every hour or so. At times of 6 - or 7 -hour nights the activity periods were often continued over into the lighted hours, suggesting that such short nights were insufficient for the daily activities. Animals studied in compartment III in dim light also followed a 24-hour cycle of activity with most of it concentrated in the dark hours, but there was much more of a tendency for the animals to expose themselves to the light.

In compartment IV with no light at any time, the animals showed an approximate 24-hour cycle of activity and quiet, but their schedule did not necessarily coincide with the natural day or with that of any neighboring group. Animals deprived of their eyes responded in a similar manner, that is, living by a 24-hour cycle of activity and rest but without regard to the light schedule of the environment.

These findings are in general agreement with those of Browman ('36) and Hemmingsen et al. ('37).

Gonadotropic hormone administration. It was found that approximately 100 rat units of Antuitrin- $S^{5}$ were required to produce the same ovarian reaction in immature Peromyscus as was produced in the albino mouse by 5 rat units. This may be due to a fundamental species difference or to the fact that one has been domesticated and laboratory bred for many generations while the other is distinctly a wild form.

Seven mature animals of series L, group IV (dark), while in anestrum, were given 20 rat units of Antuitrin-S daily for

${ }^{5}$ Antuitrin-S kindly furnished by Parke, Davis and Company. 
10 days. External observations as well as autopsy examination showed definite but not marked changes in the genitalia.

Thyroxine treatment. Since there is a strong possibility that thyroid activity may be an important factor in the determination of the breeding season, five male and four female mice 8 to 10 weeks old were injected with Thyroxine Squibb as follows: $0.01 \mathrm{mg}$. daily from May 24 to June $15,0.02 \mathrm{mg}$. almost every day from June 17 to August 12. Uninjected controls were litter mates. Basal metabolic rate was increased considerably, and spontaneous activity as measured by activity wheels was considerably greater than that of the controls, but no effect on the rate of development of the reproductive system was found. This was not repeated on adult animals in anestrum.

Cholesterol feeding. Since cholesterol is closely related chemically to the sex hormones it was considered worth while to determine whether or not that material in the diet would have any effect on sexual development of the young animal. Accordingly, it was added to the regular diet of ten young males and ten young females in the proportion of about $10 \mathrm{mg}$. per $3 \mathrm{gm}$. of food, the normal daily consumption for each animal. Nine animals, litter mates of the above were given the same except that the food including the cholesterol was irradiated with a General Electric Sunlamp or Mazda lamp for several hours in a shallow tray before it was given to the animals. The feeding was started June 28, 1937 and continued to late August. The sunlamp was used until July 20, after which the food was exposed at 33 inches to the 200 -watt Mazda lamp of compartment I for about 3 days prior to feeding. A third group of eleven animals was fed the regular diet. No difference in the age of canalization of the vagina or rate of testicular development could be detected. Perry ('38) reported enhanced sexual development in the sparrow following the feeding of ultra-violet irradiated food.

Blind animals mated. A few blinded animals were paired. Most of them produced young, showing that blinding does not produce sterility. Whether there is significance in the fact 
that much of the dor'sal pelage was kept clipped to expose the skin to light was not determined.

\section{DISCUSSION}

Although it has been general knowledge for a long time that most animals exhibit seasonal breeding, it is only recently that definite scientific attempts have been made to discover what factors of the environment are responsible for the annual cycles of reproduction.

Many investigations in recent years have shown that reproductive activity in birds, with the possible exception of tropical forms, in some cold-blooded vertebrates, and in various mammals is responsive to the length of day. Certain laboratory mammals as the guinea pig (Dempsey et al., '34), and the rabbit (Smelser et al., '34), as well as the hibernating ground squirrel (Wells, '35) are apparently not influenced to any marked extent by day length. That the Eskimo experiences a winter sterility (Cook, 1894) which might be due to the lack of light (Llewellyn, '32) has been opposed by other observers reported by Whitaker ('38), who quotes Bertelsen ('35) to the effect that the highest monthly conception rates in Greenland are for December and April.

It appears that whatever the factor or factors of the environment which may operate to determine the season of reproduction, the mating season has been established in the evolution of each species so that, in deference to the length of gestation and needs of the young animal, the young are born at the most favorable season for survival. Individuals of each species, then, are adapted to respond to a single factor or a combination of environmental factors as "cues" to set in motion the reproductive processes. It is quite obvious that these "cues" are not the same for all animals; for example, the deer mates in the autumn and the raccoon in February. Monestrous forms usually breed but once a year, but the breeding season of polyestrous mammals may extend over many months. 
The white-footed mouse appears to be the first polyestrous, wild, nocturnal mammal studied in this regard, which has given positive results. Unless some totally unforeseen factor has been overlooked in organizing the day-length experiment (groups I and II), the only variable was length of the day of artificial light, under other constant conditions of light intensity, temperature, humidity, feeding, cage conditions, and noise. Since the differences in sexual development between short day and long day periods are statistically significant to the point of practical certainty, it must be concluded that day length was the factor in determining the breeding season under the conditions of the experiment (fig. 2, table 2).

But why should a nocturnal animal be influenced by the length of day, the light of which it presumably never experiences to any considerable degree? What is the mechanism by which day length may be effective? What are the intermediate steps in this pathway between the environment and the reproductive organs? It is generally assumed, and probably correctly so, that the anterior lobe of the pituitary controls the state of development of the gonads in this phenomenon even though there is little direct evidence to support the idea. There is not available even a reasonable assiumption as to the nature of the physiological factor stimulating the pituitary to seasonal activity. The report of Benoit ('38) that light applied directly to the pituitary of the drake is sexually stimulating may aid in solving the problem, but it probably is not a factor in the normal animal. At the other end of this series of causes and effects, the effect of the environment on the organism as a whole, evidence has been produced in this investigation by which certain modes of action may be eliminated and attention directed more closely to other more reasonable possibilities.

In the first place, light on the general body surface, pelage intact, is ineffective. The eyes were the only effective receptors of light in this study. Two experiments support this conclusion. First, blind animals (series F) give no evidence of periodic sexual activity, or even of definite daily schedule of general activity. Second, those individuals of series $G$, 
which were deprived of shelter and were forced to expose their bodies to the light, but which might shield their eyes by closing them, responded in a manner similar to those of series $\mathrm{H}$ which were able to hide from the light completely.

Rowan ('38 a) has evidence to indicate that in his juncos increased periods of activity, or wakefulness, induced by longer days is the effective factor in artificially stimulating sexual activity in the winter. In a nocturnal animal, however, length of the activity period varies inversely as the day length. And, accordingly, in this study recorded activity of individual animals showed that the greatest duration of activity occurred during the long nights. It is thus apparent that increased activity cannot be the mediating factor involved. In fact, seasons of shortened daily activity (long days) coincide with the breeding season of these mice in bright light, but there was no anestrum produced by long nights interrupted by days of dim light ( 1 f.c.p. in compartment IIT). Thus, there scems to be no evidence here to support an activity theory applicable to nocturnal animals, nor is there adequate disproof of it since the eonditions were quite limited. Birds must necessarily spend much energy in procuring food for the young, and profit by a long day in which to do it. These mice, on the other hand, which feed mostly at night, appear to find 8 hours sufficient time to feed even when rearing young.

Bissonnette and Wadlund ('32) found in the starling and Bissonnette ('35 a) in the ferret that continued long days of artificial lighting prolonged into the spring and summer could not maintain a high degree of reproductive activity. A subsidence occurred following the period of maximum development. This refractory state is much more likely to be found in monestrous mammals than in the polyestrous forms, since it is likely that some refractory mechanism operates in the former to make it monestrous. The persistent eorpus luteum following ovulation in monestrons animals is probably a contributing factor. If a refractory mechanism operates to effect periodic reproductive seasons in Peromyscus, it must be conditioned by moderately bright light or moderate temperatures, because 
no cycles of brceding were observed in compartment III (light of 1 f.c.p.), in IV (continuous darkness), or in V (cold, 4 to $6^{\circ} \mathrm{C}$.). This suggests that there is no basic anestrum in the species studied and that there would be no annual changes in the reproductive system in the absence of seasonal changes in the environment.

Animals in group IIT (dim light, 1 f.c.p.) differed from those in group II (bright light, 17 f.c.p. or more) mainly by not exhibiting an anestrum. This difference is statistically significant but no certain explanation is available. In general behavior they willingly exposed themselves to the dim illumination offered much more than those of group II to the light of greater intensity. Fven so, the greatest amount of activity occurred in total darkness. Possibly this animal, being somewhat crepuscular by nature, willingly exposes itself to the dim light to such an extent that it may receive a greater daily duration of light stimulus in a short day of group III than another receives in even a long day of group II in bright light, since the latter mouse more definitely hides from the light. Which actually receives the greater amount of radiant energy has not been determined.

Available theories seem inadequate to explain the failure of the animals in group $V$ (cold, $4^{\circ}$ to $6^{\circ} \mathrm{C}$.) to experience an anestrum in the short day periods. It could not be that they exposed themselves to the light as those in group III, for they were almost never seen ont of their nosts while the light was on. Wells ('35 b) found that male ground squirrels remained in the sexual condition more or less indefinitely when exposed to a temperature of $4^{\circ} \mathrm{C}$. A difficulty in giving low temperature credit for stimulating and maintaining sexual development is the observation that mice outdoors (group VI) in the short days and low temperature of the natural winter conditions did not behave the same, but exhibited a perfectly typical anestrum.

Noise as a possible environmental factor of importance in stimulating sexual development was given no consideration in the planning of the experiment. Sound intensities (88\% pro- 
duced by the ventilating fans) were, however, measured (compare p. 40). The difference between I and II was too slight for the ear to detect. Group III exceeded II by $22 \%$, while the intensity of $V$ was almost twice that of I. If subsequent study should show that sound is influential in stimulating the reproductive system, there may be better explanations than have been offered for the lack of anestrum in groups III and $V$. Rowan (' 38 a) believes that traffic noises are responsible for an observed difference in sexual development between city and country starlings. Birds collected in February from their roosts on certain high buildings in London were considerably more developed sexually than others collected the same week in the country a few miles away.

The effect on the experimental results of the diet and caging, as such, of wild animals in the laboratory should always be kept in mind. It is believed, however, that such factors do not impose a serious error in these experiments, because the animals of group VI caged outdoors came into breeding season and produced their first litters in the spring at about the same time that the species does in the wild (Burt, in press).

Since these experiments have been in the nature of a pioneer study of the effect of light on the sexual condition of wild, nocturnal, polyestrous mammals, and definitely exploratory in Peromyscus, they are by no means complete. Certain facts seem to have been established, but many of the results are of value only in suggesting future work.

I wish to acknowledge my indebtedness to Prof. Alvalyn E. Woodward for the valuable guidance she has given me in the conduct of this study, and to the Department of Zoology for furnishing me with considerable special equipment for carrying on the research.

\section{SUMMARY}

1. More than 350 animals of Peromyscus leucopus noveboracensis, a nocturnal, polyestrous rodent with an annual anestrum in nature were used. They were observed under 
experimental conditions of artificial lighting for as long as 2 years in some cases, and examined for sexual condition every week or two. Temperature, humidity, diet, and eaging were constant through most of the 2-year period of the study.

2. In light of 15 to 32 foot candle power intensity, varying in daily duration on an annual schedule, the anestrum occurred in the short day season.

3. In light of the low intensity of 1 foot candle power, breeding activity continued throughout short day as well as long day portions of the year.

4. Animals at lower temperatures $\left(4^{\circ}\right.$ to $6^{\circ} \mathrm{C}$.) and light of about 15 f.c.p. also failed to go into anestrum in short days, but produced litters at all seasons, which were, however, seldom reared successfully.

5. Animals blinded by removal of the eyes were not rendered sexually sterile but exhibited no cyclic tendency to breeding activity.

6. Those kept in continuous darkness exhibited a lowered and entirely non-cyclic reproductive activity.

7. That the results given in 3 and 4 above might possibly be due to noise disturbance is presented in the discussion.

8. Certain other related experiments are described.

\section{LITERATURE CTTED}

Allanson, Marioniw, ANJ R. DeAdesLy 1934 The reaction of anocstrous hedgehogs to experimental conditions. Proc. Roy. Soe. s. B., vol. 116, pp. $170-185$.

BAIEER, J. R., AND R. M. RANSON 1932 a Factors affecting the breeding of the field mouse (Microtus agrestis). Part I. Light. Proe. Roy. Soe, s. B., vol. 110, pp. 313-322.

$1932 \mathrm{~b}$ Ibid. Part II. Temperature and food. Proc. Roy. Soc., s. B., vol. 112, pp. 39-46.

1933 Ibid. Part III. Locality. Proe. Roy. Soc,, s. B., vol. 113, pp. 486-495.

BEnoIT, J. 1938 Action de divers Éclairements localizés dans la région orbitaire sur la gonadostimulation chez le Canard male impubéré. Croissance testiculaire provoquée par l'Éclairement direct de la région hypophysaire. Compt, rend. Soc. de biol., vol. 127, pp. 909-914.

Brrtelsen, A. 1935 Grọnlandsk Medieinsk Statistik og Nosograf. Meddelelser om Grønland, Bd. 117, Nr. 1, pp. 1-80. 
BrssonnerTe, T. H. 1932 Modifieations of mammalian sexual eycles; reactions of ferrets (Putorius vulgaris) of both sexes to electric light added after dark in November and December. Proc. Roy. Soe., s. B., vol. 110, pp. 322-336.

1935 a Modification of mammalian sexual cycles. III. Reversal of the cycle in male ferrets (Putorius vulgaris) by increasing periods of exposure to light between Oetober second and March thirtieth. J. Exp. Zool., vol. 71, pp. 341-373.

$1935 \mathrm{~b}$ Modification of mammalian sexual eyeles. IV. Delay of oestrus and induction of anoestrus in female ferrets by reduction of intensity and duration of daily light periods in the normal oestrous season. J. Exp. Biol, vol, 12, pp. 315-320.

1936 Sexual photoperiodicity. Quart. Rev. Biol., vol. 11, pp. 371-386. 1937 Photoperiodicity in birds. Wilson Bull., vol, 49, pp. 241-270.

Bissonnetre, T. H., AND EARL E. BAILEy 1936 Litters from ferrets in January induced by increased exposures to light after nightfall. Amer. Nat, vol. 70 , pp. $454-458$.

BIssorNetTe, T. H., AND A. G. CSECH 1937 Modification of mammalian sexual cycles. VII. Fertile matings of raccoons in December instead of February induced by increasing daily periods of light. Proc. Roy. Soc., s. B., vol. 122 , pp. 246-254.

1938 Sexual photoperiodicity of raccoons on low protein diet and second litters in the same breeding season. J. Mammal, vol. 19, pp. 342--348.

BissonnetTe, T. H., AND A. P. R. WAdLUND 1932 Duration of testis activity of Sternns vulgaris in relation to type of illumination. J. Exp. Biol., vol. 9, pp. 339-350.

Browman, L. G. 1936 Light in its relation to activity and estrous rhythms in the albino rat. Anat. Rce., vol. 67, suppl, 1, p. 107.

Burt, W. H. Miscellaneous Publications, Museum of Zoology Series, University of Michigan. (In press.)

Cook, F. A. 1894 Medical observations among the Esquimaux. Tr. New York Obst. Soc. 1893-1894, pp. 171-174.

Dempsey, E. W., H. I. Mrers, W. C. Young And D. B. Jennison 1934 Absence of light and the reproductive eycle in the guinea pig. Am. J. Physiol, vol. 109, pp. 307-311.

Diof, I. R. 1934 An improved Peromyseus ration. J. Mammal., vol. 15, pp. 160161.

Hemmingses, Axel M., and Niels B. Krarup 1937 Rhythmie diurnal variations in the oestrus phenomena of the rat and their susceptibility to light and dark. K. Danske Videnskabarnes Selskab. Biologiske Meddelelser, vol. 13, no. 7 .

Hill, Margaret, aNd A. S. Parkes 1933 Studies on the hypophysectomized ferret. IV. Comparison of the reproductive organs during anoestrus and after hypophysectomy. Proe. Roy. Soe. London, s. B., vol, 113, pp. $531-536$.

1934 Effect of absence of light on the breeding season of the ferret. Proc. Roy. Soe. London, s. B., vol. 115, pp. 14-17. 
ILEWELLYN, LL. J. 1932 Light and sexual periodicity. Nuture, London, vol. 129, p. 868 .

Marshalr, F. H. A. 1936 Sexual periodicity and the causes which determine it. Phil. Tr. Roy. Soc., London, s. B., vol. 226, pp. $423-456$.

Miller, Garrit S. 1893 On the introitus vaginae of certain Muridae. Bost. Soc. Nat. Hist., vol, 26 , pp. 459-468.

Perry, J. C. 1938 Influenee of diet on gonad activity of English sparrow, Passer domesticus (Linnaeus). Proc. Soc. Exper. Biol. and Med, vol. 38 , pp. 716-719.

Rowan, WILLIAM 1925 Relation of light to bird migration and developmental changes. Nature, London, vol. 115, pp. 494-495.

1938 a London starlings and seasonal reproduction in birds. Proc. Zool. Soe., London, s. A., vol. 108, pp. 4-77.

$1938 \mathrm{~b}$ Light and seasonal reproduction in animals. Biol. Rev, vol. 13, pp. 374.402.

SMelser, G. K., ARThur WaltoN AND E. O. Whetham 1934 The effect of light on ovarian activity in the rabbit. J. Exp. Biol., vol. 11, pp. 352-363.

WELLs, L. J. 1935 a Seasonal sexual rhythm and its experimental modification in the male of the thirteen-lined ground squirrel (Citellus tridecemlineatus). Anat. Ree, vol. 62, pp. 409-447.

$1935 \mathrm{~b}$ Prolongation of breeding capacity in males of an annual breeding wild rodent (Citellus tridecemlineatus) by constant low temperature. Anat. Rec., vol. 64 (suppl. no. 1), pp. 138-139.

WHITAKER, W. L. 1936 Effect of light on reproductive cycle of Peromyscus leucopus noveboracensis. Proc. Soc. Exper. Biol. and Med., vol. 34, pp. 329-330.

1937 A method for studying environmental choices of laboratory animals. Science, vol. 86 , p. 314 .

1938 The question of a seasonal sterility among the Eskimos. Seience, vol, 88, pp. 214-215. 